\title{
MAN AND HIS QUALITY AS AN IMAGE OF GOD IN PATRISTIC THINKING
}

\author{
Phd. Student Edvica POPA, \\ "Ovidius" University of Constanta, \\ ROMANIA \\ E-mail: edvica_popa1@yahoo.com
}

\begin{abstract}
The notion of divine image is generously described by the patristic literature, each of the authors trying to identify the content of this special characteristic of human being, considered (in different positions) the defining element of the created rational being, indicating the possibility of opening to God not through something external, but from the inside of the human being. Since when they speak of God, the Church Fathers do not consider the reality of the one being, but that of the three persons, the Father, the Son and the Holy Spirit, as well as when the question of the image of God is raised, they emphasize that this the image by which human nature is conformed is the image of the Son, or the image of the Word. In this article I set out to draw some points on this patristic feature of the Eastern Fathers.
\end{abstract}

Keywords: archetype; anthropology; creation; divine image; divine likeness; logos.

\section{INTRODUCTION}

Patristic thinking did not stop only at the generic consideration of man as the "face of God". Whereas when imparting about God, the Holy Fathers do not consider the reality of the one being, but that of the three persons, the Father, the Son, and the Holy Ghost, the same when it comes to the question of the "face of God", it is made clear that this face by which human nature is conformed is the face of the Son, or the face of the Word.

This identification with the "face of the Son" is also linked to the fact that the face of the fallen man in sin is restored by the saving work of the Son of God, Jesus Christ. Hence a differentiation in "old Adam" and "new Adam", between the pre-fall state and that of the human in Christ. "Of the Holy Fathers, most confirm, in different ways, the relativity of Adamic perfection, in those they say when they compare life in Adam to that in Christ, and when they distinguish between image and likeness. Indeed, by comparing creation to redemption, the Fathers generally declare that redemption through Christ is the return to original righteousness and the restoration of God's face in Adam. In particular, when they make the connection between creation and redemption, they raise the latter, saying that the state in paradise was not perfect, but was inferior to that in Jesus Christ, among other things, and because it was devoid of intemperance and spiritual life, which is given by Jesus Christ. In other words, restoration and spiritual life in Christ is the end point that the natural man was to reach before the fall, after I Cor. 15, 46 sq., bearing moral trial and, in particular, promoting free will in perfect natural freedom" ${ }^{1}$.

${ }^{1}$ Hr. Andrutsos, Symbolic, Trans. by Justin Moisescu, Edit. Metropolitan Center of Oltenia, 1955, p. 232. 


\section{HRISTOLOGY IN THE PATRISTIC DOCTRINE}

The teaching about the quality of the Son's face has a strong biblical foundation from which the Holy Fathers also departed. In the Epistle to the Colossians, St. Paul produces a synthesis of the teaching of Christ - the face of God - presenting it not as a personal opinion but "as a liturgical hymn of the Christian community": "He is the unseen face of God, First Born of all the building, for in Him were all built, those in heaven and those on earth , the seen and the unseen, either Thrones, or The Lords, or the Beginners, or the Masters. All through Him and for Him have been built, and He is before all, and all in Him are held together, and He is the head of the body, of the Church, He, who is the beginning, the First Born of the dead, that He may be the first in all" (Colossians 1, 15-18). ${ }^{2}$

The text reveals the Christological aspect par excellence of Pauline anthropology, implicit of the Theology of the Face. This dimension of the term face is manifested in the fundamental teaching of St. Paul according to which, in order to be whole, man must bear the face of the heavenly man, that is, of Christ (I Corinthians 15, 49), reach the stature of the age of Christ's fullness (Ephesians 4, 14) and this "that he may no longer be a child." For the apostle of the Gentiles, the majority of man coincides with his christification, and implicitly his destiny is a histological one. "The exhortation of St. Paul to the faithful man that he ${ }^{3}$ should appear as a perfect man, to the extent of the age of Christ's fullness (Ephesians 4, 13), acquire the mind of Christ (I Colossians 2, 16), the heart of Christ (Ephesians 3, 17), is not made for reasons of external piety and sentimentality, but he speaks ontologically. ${ }^{4}$

This is based both on the teaching that man is the face of Christ and on the dynamism that the face has. It is the calling of his own nature - the christic nature - as well as the voice of love that calls him to the Absolute Love of the Holy Trinity through which he was created. Therefore, the teaching that man is the face of Christ does not overshadow that of man - the face of the Holy Trinity. It is an explanation rather than a contradiction between the two teachings. "So the Lord has not done mankind only one good as any other, keeping his best part for Himself, but has made us partakers of the very fullness of God, loading himself with all the wealth of gifts that flow from His Being."

This is proven by the Holy Fathers, those who take over the idea of Pauline Christ the face of God - have linked it to the theme of the Face, the man - the face of God resulting in the teaching of man - the face of the Face. For St. Irenaeus, Clement Alexandrine, Origen, St. Athanasius, St. Gregory of Nyssa, St. Maxim, St. Gregory Palama and for almost all other Fathers it is clear the distinction that Christ represents the Face of God and man the face of Christ, so that man is the face of the face.

St. Irenaeus says that the image of God is the Son, in whose face man was, and $\mathrm{He}$ showed himself at the fullness of time in order to discover that the face was his. The stature of the face implies that of the likeness, and the creation of man participates the whole Trinity, God creating all through His Word, and embellishing them through the Holy Spirit. In this context, the Word is the Archetype by which the Holy Trinity shapes man.

"Man is assimilated to the Logos through the rational part of his soul," and through the intercession of the Logos man becomes a friend of God. "In fact," says Cabasila, "any

\footnotetext{
${ }^{2}$ Panayotis Nellas, Man - godly animal, Trans John I. Ica. Jr. ed. a II-a, Edit. Deisis, Sibiu, 1999, p. 107.

${ }^{3}$ Panayotis Nellas, Man - godly animal, p. 67.

${ }_{5}^{4}$ Panayotis Nellas, Man - godly animal, p. 81.

${ }^{5}$ Nicolae Cabasilas, Despre viaţa in Christ, Trans Prof. Prof. Dr. Teodor Bodogae, EIBMBOR, Bucureşti, 2001, p. 34.
} 
friendship leads in forced form to some union; but what could God's love resemble? It seems that the bond and the union between the spouses, on the one hand, and the harmony of listening to the cocks, on the other, would best clarify this mysterious union. Yet even these images are poorly tally and remain far from what they should say. "The purpose of the face is the likeness, which in Clement's conception consists in the participation of our logos in the divine Logos.

An important step in understanding the human being - the face of God is taken by St. Gregory of Nyssa. If at St. Athanasius everything revolves around the Logos and His work, St. Gregory leans on man and the value he has in the universe. "The object of my research is not at all simple-writes the Saint-being no more important than the wonders of the world, but in a way it is more precious than any of what is known in the world because apart from man no other creature resembles God." By this likeness man is an integrative part of the universe. If for the stoics and for many of the Holy Fathers man is microcosm, for St. Gregory, he becomes macrocosm. The two terms do not contradict each other, but the first makes sense in the second. Being from this world, the human person shares in its contents, but cannot remain in the sphere of the limited, but aspires to something better, to his archetype to which he is mysteriously bound. "There is a great difference between the man who was built to resemble the model and what was made after some kind of face around him. For if the face bears no resemblance to the model, then it is not worthy to bear its name. If the imitation is not complete, we are dealing with something else, not with the face or reproduction of the original." 6

The approach of St. Gregory of Nyssa is deeply anthropological. Through a thorough demonstration he bases the true status and the authentic purpose of man: that of deestablishing himself and of deified the world in which he lives, and P. Nellas emphasizes this further by stating that "the purpose of the first man always remains the same. Every man created in the image of God is created to become a face in Christ... Christ paved the way for this goal. Indeed, the birth of God the Word and His iconography in the flesh do not exhaust itself in redemption, in liberation from the consequences of Adam's error." ${ }^{7}$

This human connection - Logos appears insistently in the writings of the Holy Fathers, which proves the importance it has in the formulation of the teaching of faith. The fact that man has as archetype the Logos, is undoubtedly one of the fundamental truths of the Church, but the Fathers have made one more point: The Archetype of man is the Incarnate Logos. Thus, even "before the hypostatic union of divine and human nature, and even before the fall, man existed for Christ, which means that he had even then, although he had not sinned, the need for salvation, since he was unfulfilled and unfulfilled, child."8

The realization of man as a truly whole being took place through the birth of Christ, which is why St. Basil the Great rightly calls the day of Christ's birth "the birthday of humanity"'.

Nicolae Cabasilas, resuming St. Gregory of Nyssa, states the following: "because for the new man was made up from the beginning the nature of man; mind and desire were made for Him: the mind they received to know Christ, the desire to run to Him, the memory we have to carry in him, for He was the Archetype for the walled. Because it's not the old Adam

\footnotetext{
${ }^{6}$ St. Gregory's Nyssa, Introduction the About Making Man, in vol. Writings Part II, Trans Pr. Prof. Teodor Bodogae, PSB 30, Edit. Biblical Institute..., Bucureşti, 1998.

${ }^{7}$ Panayotis Nellas, Man - godly animal, p. 80.

${ }^{8}$ Panayotis Nellas, Man - godly animal, p. 79.

${ }^{9}$ St. Basil the Great, the naşterea Christ, apud P. Nellas, Op. Cit. p. 80.
} 
that's the model for the new Adam, it's the new Adam that's the model of the old one... man goes to Christ not for his deity which is the goal of all, but also because of his other nature (the human one). ${ }^{10}$ The fact that Adam was created in the image of Christ means that "he received, as the face, the breath of the Spirit and effectively showed himself as a living soul (Face 2,7$) \ldots$ the man before the fall was not yet able to receive the hypostatic union and find in it his true existence and full spiritual life. Through the birth of the happy body of the Lord takes place the union of the two natures spaced until then because the common hypostasis suppresses the distance between divinity and humanity..." ${ }^{11}$.

Then, through the Passion and sacrifice of the Savior's Cross, both sin and the power that the devil had over man are crushed; human nature is freed from enmity with God and is brought to the luminosity and beauty of paradise. Through His Resurrection, man is freed from his service to damage and death; "descending with the human nature which he took, and through it to death, the Word renewed and made man unsparing. Through the Resurrection, the truly human body of Jesus became and showed himself immortal and spiritual body..." 12 . Human nature was built in the image of Christ, "so that the Logos could take From it His Mother and enter the world as a man, so that God would truly become God-man, and man would become truly, according to grace and participation, himself God-man." ${ }^{13}$ Therefore, man must tend toward his Archetype, "to participate in the deity by releasing from any possibility of sin and by strengthening in love, so that the Word may unite hypostatically with man and thus appear in Christ's history, may God-Man-be shown." 14 Man is called to participate in God, without his nature ever being confused with that of God, without his freedom being diminished; on the contrary, "in Christ, man finds his primary destiny restores his existence according to the divine Model, rediscovers true freedom lost because of the bondage to which Satan subjected him-by working with the Holy Spirit, to love and know God." ${ }^{15}$ Spiritualization means "to imitate Christ, that is, to endure His passions on the path of asceticism, to enlighten yourself with the truth revealed through Him in order to reach full life... Any action is directly proportional to the purpose you're pursuing. But the purpose of religious life is deity. But such a great purpose requires a preparatory action to match it... The measure of godliness is God Himself." 16

\section{LIMITS OF HUMAN FREEDOM IN THE PATRISTIC TEOLOGY}

The archetype of man is therefore not simply the Logos, but the incarnate Logos. Therefore, the image of Christ is not something impossible for man to achieve, because "The chip of God is a real possibility, a pledge of engagement that must lead to the wedding, that is, to the hypostatic union, the unmixed but real mixture of divine and human nature. Only then does the iconic or potency-like existence of man become a real existence. Man finds his ontological content in the Archetype." ${ }^{17}$ Therefore, here on earth is born the new man or the inner man, made in the image of God, "being like a fetus in the womb of his mother, and

\footnotetext{
${ }^{10}$ N. Cabasilas, Op.cit., apud P. Nellas, Op. Cit. p. 77.

${ }^{11}$ Panayotis Nellas, Man - godly animal, p. 137, 139.

${ }^{12}$ Panayotis Nellas, Man - godly animal, p. 139-140.

${ }^{13}$ Panayotis Nellas, Man - godly animal, p. 142.

${ }^{14}$ Panayotis Nellas, Man - godly animal, p. 78.

${ }^{15}$ John Meyendorff, Christ in thought creştină Eastern Trans Pr. Prof. Nicolai Buga, Edit. Biblical Institute..., Bucureşti, 1997, p. 137.

${ }^{16}$ Nichifor Crainic, Sfinţenia - the fulfillment of the human, Edit. Metropolitan of Moldova Chi minh city Bucovina Iaşi, 1993, p. 110, 115.

${ }^{17}$ P. Nellas, Op. Cit. p. 79.
} 
after having taken full form is born so-called the second time for the other world, perfect and unvarnished." 18

The dynamism of the face goes beyond the moral meaning of a similarity seen as the fulfillment of certain norms, revealing an authentic, christic meaning. "Man-the face of the Word is the great mystery, and the union between man and Christ is a happy target for which all have been founded. This is the divine purpose, thought before the beginning of things, which, by defining it, we say is the final target, previously thought out, for which they are all, and it for none." ${ }^{19}$ This final target to which every believer aspires, the deity, is possible no other than through God's work in us; protecting us from the evils to which the devil urges us, the Lord has given us the face, to follow Him. "He who truly partakes in Christ, he cannot fail to do everything as Christ himself did. He who truly loves Christ, he will truly keep His commandments, for it is impossible that, by loving Christ, you do not love His commandments in which the spirit of Christ is expressed." 20

This dynamic aspect was essential for the spiritual literature in which human tension to God occupies the most important place. The face is shaped directly in relation to man's virtue before God and his love for his fellow man. The love of guests and strangers within the monastic community such as that of Nitria or Sketis is telling proof of this. The answer given by an old man, Avva John Cassian, and German, his companion, is revealing: "the fast is always with me, but you always keep with me, I cannot... Receiving, but through you I owe it my best to rest Christ. And after I spend you, the canon of the station I can win it again." 21

Archimandrite Sophrony describes in an exceptional way the love relationship between man and Christ, which is intended, almost involuntarily, for the love of his neighbor: "God's love is his own insatus: she does not know and cannot know the satiness. There is no stink, no rinsing in the energy of undisplaced life... In the act of Christ-like love, the Christian gives himself without the remnant of his other lovers: first of all to God, and then, in the power of the Holy Ghost, to all."22 We could say that what man has received, only contoured at creation, receives color through working faith in deeds, or that the Good Painter works with us to realize the similarity. If we have received the face and we must come to the likeness of God, in what way is the likeness expressed, asks Archimandrite Sophrony; and he also replies, "Especially in the fact that he will bear upon himself the hardships of his brethren, that is, he will count himself guilty of the evil that takes place, and gradually growing in this consciousness, he will receive all death willingly, without even looking where it comes from and what kind it is." 23

\section{CONCLUSION}

We must reject everything to look at Christ, but because every man is the face of Christ, we have a duty to look at him and surround him with love. We are not surprised that that old man has renounced the severe rule of fasting precisely to receive the neighbor - the face of Christ, and his gesture is nothing more than a determined step towards salvation and

\footnotetext{
${ }^{18}$ N. Cabasilas, Op. Cit. p. 22.

${ }^{19}$ St. Maxim the Confessor, Responses to Talasie LX, Trans Prof. D. Stăniloae in Filocalia, vol. III , Edit. Humanitas, Bucureşti, 1999, p. 304.

${ }^{20}$ Archimandrite Sophrony, Naşterea the one in împărăţia the unflinching one, Edit. Reunification, Alba-Iulia, 2003, p. 251.

${ }^{21}$ Lucien Regnault, Viaţa daily life părinţilor deşertului in 4th century Egypt, Trans John, I'm going to I. Ica Jr., Edit. Deisis, Sibiu, 1997, p.156.

${ }^{22}$ Archimandrite Sophrony, Naşterea the one in împărăţia the unflinching one, p. 128.

${ }^{23}$ Archimandrite Sophrony, Naşterea the one in împărăţia the unflinching one, p. 251.
} 
deity. That is why he becomes an intermediary between the universe and God tending towards loving communion with fellow men according to the paradigm of intra-trinity love.

In conclusion, Christ raised in man the image of God to his full topicality, that is to say to his full communion with God and his fellowmen, and what Christ expects of us is to leave the truffle and raise our gaze to heaven, "for in the other time of our lives only one thing is required: to keep the blessings and gifts shared by Christ, and not to cast out our crown., which with so much fatigue and effort the Savior has woven us. Only this and is life in Christ, the life that the Holy Mysteries gain, to which, of course, is added the benevolent endeavor of man." 24

\section{BIBLIOGRAPHY:}

[1] Andrutsos Hr., Symbolic, Trad. by Justin Moisescu, Edit. Metropolitan Center of Oltenia, 1955,

[2] Panayotis Nellas, Man - godly animal, Trad. John I. Ica. Jr. ed. a II-a, Edit. Deisis, Sibiu, 1999, p

[3] Cabasila Nicolae, About viaţa in Christ, Trad. Prof. Prof. Dr. Teodor Bodogae, Edit. Biblical Institute..., Bucureşti, 2001,

[4] Gregory's St. Nyssa, Introduction the About Making Man, in vol. Writings Part II, trad. Pr. Prof. Teodor Bodogae, PSB 30, Edit. Biblical Institute..., București, 1998.

[5] Meyendorff John, Christ in thought creştină Eastern Trad. Pr. Prof. Nicolai Buga, Edit. Biblical Institute..., Bucureşti, 1997,

[6] Crainic Nichifor, Sfinţenia - the fulfillment of the human, Edit. Metropolitan of Moldova Chi minh city Bucovina Iaşi, 1993

[7] Maxim St. the Confessor, Responses to Talasie LX, trad. Prof. D. Stăniloae in Filocalia, vol. III , Edit. Humanitas, Bucureşti, 1999,

[8] Sophrony Archimandrite, Naşterea the one in impărăţia the unflinching one, Edit. Reunification, Alba-Iulia, 2003,

[9] Regnault Lucien, Viaţa daily life părinţilor deşertului in 4th century EgyptTrad. John, I'm going to I. Ica Jr., Edit. Deisis, Sibiu, 1997

${ }^{24}$ Nicolae Cabasilas, About life in Christ, p. 47. 